\begin{tabular}{l}
$\begin{array}{c}\text { Yanbu Journal } \\
\text { of }\end{array}$ \\
$\begin{array}{l}\text { Engineering } \\
\text { and Science }\end{array}$ \\
\hline \hline ISSN: $1658-5321$
\end{tabular}$\quad$ Vol. 7, October $2013(1434 \mathrm{H})$

ISSN: $1658-5321$

www.yjes.org.sa

\title{
KINETICS STUDY OF THE REACTION OF HYDROGENATED DIMER FATTY ACID C36 WITH 1,7 DIAMINOHEPTANE : DETERMINATION OF THERMODYNAMIC CONSTANTS
}

\author{
H .Mohammad, M. Alhammuie, and A. Falah \\ Department of Chemistry- Faculty of Science, Damascus University, Syria \\ Syria-Hassan19801980@yahoo.com
}

\begin{abstract}
Kinetic studies were carried out on the reaction between 1, 7 diamino heptane and hydrogenated C36 dimer fatty acid in melt phase. The reaction was performed at 110, $130,135,140$, and $150{ }^{\circ} \mathrm{C}$ and was followed by determining the acid number of the reactant acid. The polyamidation reaction was found to be of overall second order with an activation energy of $44.0 \mathrm{~kJ} / \mathrm{mol}$ up to $78,82,76,75,74 \%$ conversion at 110,130 , $135,140,150^{\circ} \mathrm{C}$ and after the former conversions the reaction will become third order. The degree of polymerization, number average molecular weight, and weight average molecular weight have been calculated during different times. The relationship between degree of polymerization, number average molecular weight and weight average molecular weight with time is linear until $(78,82,76,75,74) \%$ conversion at $(110,130$, $\left.135,140,150^{\circ} \mathrm{C}\right)$. The kinetics of degradation was carried out by the use of thermal analysis TGA, thermodynamic and equilibrium constants of degradation have been determined. The kinetics of degradation was found to be of overall second order. It was assured of the structure of resulting poly amide by use infra-red spectroscopy.
\end{abstract}

Keywords: Kinetic, Thermodynamic Constants, Dimer Acid.

\section{INTRODUCTION}

Fatty polyamides are condensation products of di- and polyfunctional amines and di- and polybasic fatty acids[1]. The latter are obtained by the polymerization of unsaturated fatty acids or their esters. Fatty polyamides can be broadly classified into two categories: un-reactive and reactive. The un- reactive polyamides have a far lesser number of primary and secondary amine groups to react with epoxy resins compared to the reactive ones. These polyamides also differ in their properties and therefore in their end uses. Un -reactive polyamides are mostly solids and are used in the printing ink industry, thermo setting, adhesives [2]. The reactive polyamides are mostly liquid and are used in the surface coatings, adhesives industry[3-4]. Dimer acidbased polyamides were prepared due to their singular molecular structure based on their dimer acid relatively good performance [5-6]. Much of the literatures on fatty polyamide preparation are patented [1-2,7].Un -reactive polyamides were prepared by reacting a mixture comprising of polymeric fatty acids, diamines such as ethylene diamine and hexamethylene diamine and an aliphatic monobasic acid or amine, to obtain a product desired, degree of polymerization, number average molecular weight, viscosity and softening point. Most of these polyamides have properties comparable to the commercially available polyamides used in 
flexographic inks, adhesives and overprint varnishes [8]. Renewable biocomposites of dimer fatty acid - based polyamides with cellusoe fibers were prepared and studied their thermal, physical, mechanical properties and yield behaviour and high strain rate behaviour [9-11]. The Influence of monofunctional reactants on the physical properties of dimer acid - based polyamides was studied where dimer acid-based polyamides were synthesized by condensation polymerization in the absence and presence of reactants. Acetic acid, oleic acid and propyl amine were used as monofunctional reactants [12]. Much of the literature has been reported on the kinetics of this reaction such as nylon- 6 and nylon- 6,6 [13] and reaction of dimeric fatty acids $\mathrm{C}_{36}$ with Ethylenediamineat $(124,130,145$, $160,174,190){ }^{\circ} \mathrm{C}[14]$, as well as the reaction between ethylenediamine and dimer fatty acids in benzyl alcohol solution at $(160-190)$ ${ }^{\circ} \mathrm{C}$ [15]. A generally applicable stoichiometric and kinetic model was developed for the polymerization of dimer fatty acid with Ethylenediamine. Comparison of the model prediction with the experimental data showed that the approach is useful in the predicting the polymerization kinetics [16]. A generally applicable stoichiometric and kinetic model was developed for the polymerization of dimer fatty acid with ethylene diamine in melt phase in the presence of phosphoric acid as catalyst at (132-202) ${ }^{\circ} \mathrm{C}$ [17]. The kinetics of the reaction between ethylene diamine and dimeric fatty acids was studied in melt phase in the range of (162-202) ${ }^{\circ} \mathrm{C}$ above $90 \%$ conversion [18]. Thermal analysis refers to a variety of techniques in which a property of a sample is continuously measured through a predetermined temperature profile. Endothermic and exothermic reactions or phase changes in the sample undergo to changes in temperature between the sample and the furnace to more than one degree[19]. There are many methods of thermal analysis, but the present discussion will be limited only in the techniques that are used in determining the properties of polymers are: thermo gravimetric analysis TGA. By TGA a small amount of the sample is weighed and put in the oven of the TGA apparatus, then the continuous change of mass with temperature under fixed pressure is recorded in the presence of nitrogen. The temperature of sample is gradually increased. One of the applications of TGA is study the kinetics of degradation, But not only the kinetics of this reaction in melt phase for preparing dimer acid-based polyamides with 1, 7 diamino heptane, but also kinetics of degradation of polyamide by use TGA and determination of thermodynamic constants have not been reported by any work. In our work we will study kinetics of this reaction in melt phase for preparing dimer acid-based polyamides with 1, 7 diamino heptane, and we will apply technique of TGA for kinetics of the degradation and determination thermodynamic constants.

\section{EXPERIMENTAL}

\subsection{MATERIALS}

Hydrogenated dimer fatty acid $\mathrm{C}_{36}$ was from Sigma - Aldrich and was $97 \%$ pure and had density $0.95 \mathrm{~g} / \mathrm{ml}$, while 1,7 diamino heptane is colorless solidified mass, it was laboratory reagent grade having purity of above $98 \%$ as determined by titration with standard acids and had melting point 26-29 ${ }^{\circ} \mathrm{C}$. All other materials were reagent grade.

\subsection{METHOD}

A one liter round bottom Flask, equipped with stirrer, nitrogen inlet tube, thermo well, Dean-Stark apparatus and addition funnel, was charged with known weight of dimeric fatty acid and heated in an isomantle. An equivalent molar quantity of 1,7 diamino 
heptane was added within $2 \mathrm{~min}$, and the heating was regulated to get the desired temperature within 15 minutes. The polyamidation reaction was carried out at five different temperatures in the range of 110 $150^{\circ} \mathrm{C}$. In this temperature range the reaction mass remained in molten state. The water generated during the reaction was swept out of the system by nitrogen bubbled through the reacting melt and collected in the DeanStark apparatus. This helped the reaction to go in the forward direction. The samples were taken out at intervals and analyzed for acid value. The acid values were determined using a neutral solution $(50 / 50, \mathrm{v}: \mathrm{v})$ of methanol and tetrahydroforan for dissolving the samples and then the Degree of Polymerization,
Number Average Molecular Weight and Weight Average Molecular Weight have been calculated during different times, when the reaction was finished the kinetics of degradation for the result polyamide were carried out by the use of thermal analysis TGA. Thermodynamic constants for degradation were determined by use thermal analysis TGA and infra-red spectroscopy for determination of resulting compound structure.

\subsection{PREPARITION OF POLY (HYDROGENATED DIMER FATTY ACID $\mathrm{C}_{36}$ WITH 1, 7 DIAMINO HEPTANE)}

Polyamide were prepared from hydrogenated dimer fatty acid $\mathrm{C}_{36}$ and 1, 7 diamino heptane as in following equations:

\section{$\mathrm{n} \mathrm{HOOC}-$ Dimer $-\mathrm{COOH}+\mathrm{n} \mathrm{H}_{2} \mathrm{~N}-\left(\mathrm{CH}_{2}\right)_{7}-\mathrm{NH}_{2} \longrightarrow$-OC-Dimer $-\mathrm{CONH}-\left(\mathrm{CH}_{2}\right)_{7}-\mathrm{NH}{ }_{\mathrm{n}}+2 \mathrm{n} \mathrm{H}_{2} \mathrm{O}$ \\ Dimer acid 1,7 Diamino heptane poly(Dimer acid-1,7 Diamino heptane)}

\subsection{THE EQUATION OF KINETICS REACTION FOR SECOND ORDER}

The following equation is used for the second order kinetics:

$$
\frac{1}{C_{A}}-\frac{1}{C_{A_{0}}}=k t
$$

Where: $\mathrm{C}_{\mathrm{Ao}}$ and $\mathrm{C}_{\mathrm{A}}$ are the carboxyl end group contents present initially and at time $\mathrm{t}(\mathrm{min})$, respectively, expressed as $\mathrm{m} . \mathrm{mol} \mathrm{Kg}^{-1}, \mathrm{k}$ is the second order rate constant expressed as: $\left(\mathrm{m} . \mathrm{mol} \mathrm{Kg}^{-1}\right)^{1-\mathrm{n}}(\text { time })^{-1}$, and $\mathrm{t}$ is the reaction time (min).

If $\mathrm{A}_{v o}$ and $\mathrm{A}_{v}$ are the acid values: $\mathrm{mg} \mathrm{KOH} / \mathrm{g}$ polymer at time $t=0$, i.e., the time at which both the reactants are brought into contact, and at time $\mathrm{t}$ ( $\mathrm{min})$, respectively, by acid number equation we can calculate $\mathrm{C}_{\mathrm{A}}, \mathrm{C}_{\mathrm{A} 0}$.

$$
A_{v}=\frac{\left(V_{2}-V_{1}\right)(0.0561)(1000) N}{W}
$$

where: $\mathrm{W}=1 \mathrm{~g}=10^{3} \mathrm{mg}$

$$
\begin{aligned}
& A_{v}=\frac{\left(V_{2}-V_{1}\right) N 56.1}{10^{3}} \\
& A_{v} 10^{3}=\left(V_{2}-V_{1}\right) N 56.1 \\
& N\left(V_{2}-V_{1}\right)=N V=\frac{\left(A_{v}\right) 10^{3}}{56.1} \\
& C_{A}=N V=\frac{\left(A_{v}\right) 10^{3}}{56.1}
\end{aligned}
$$

then $\mathrm{C}_{\mathrm{Ao}}$ and $\mathrm{C}_{\mathrm{A}}$ can be expressed as:

$$
C A_{0}=\frac{10^{3}(A v)_{0}}{56.1} \quad C A=\frac{10^{3}(A v)}{56.1}
$$

Hence eq. (1) can be written as

$$
\frac{1}{A_{V}}-\frac{1}{A_{V_{0}}}=\frac{k t}{0.0561}
$$

\subsection{THE RELATIONSHIP BETWEEN REACTION RATE CONSTANT AND TEMPERATURE}

The relationship is given by Arrhenius equation:

$$
k=A \exp ^{-E_{a} / R T_{s}}
$$


where $\mathrm{k}=$ reaction rate constant $\left[(\mathrm{mol})^{1-}\right.$ $\left.\mathrm{n}(\text { time })^{-1}\right], \mathrm{T}=$ absolute temperature, $\mathrm{n}=$ order of reaction, A: pre-exponential factor $(\mathrm{mol})^{1-}$ ${ }^{n}(\text { time })^{-1}, E=$ activation energy $(\mathrm{k} \mathrm{J} / \mathrm{mol})$.

\subsection{DETERMINATION OF DEGREE OF CONVERSION:}

The degree of conversion [20] is determined according to the following equation:

$$
P=\frac{A_{v_{0}}-A_{v}}{A_{v_{0}}} \times 100
$$

Where:

$\mathrm{Av}_{0}$ : the acid number in the time $t_{0}$ (before reaction)

$A_{v}$ : the acid number in the time $t$

The acid number $A_{v}$ is given by the weight of $\mathrm{KOH}$ in $\mathrm{mg}$ required to neutralize $1 \mathrm{~g}$ of substance.

\subsection{DETERMINATION OF NUMBER AND WEIGHT AVERAGES OF MOLECULAR WEIGHT}

The number average of molecular weight $\mathrm{Mn} \mathrm{[20]} \mathrm{is} \mathrm{determined} \mathrm{according} \mathrm{to} \mathrm{the}$ following equation:

$$
\begin{gathered}
X_{n}=\frac{M_{0}}{(1-p)} \\
M_{n}=X_{n} M_{0}=\frac{M_{0}}{(1-p)}
\end{gathered}
$$

$\mathrm{M}_{0}$ :the molecular weight for monomer

P:conversion degree

Where the weight average of molecular weight Mw [20] is determined according to the following equation:

$$
\begin{gathered}
M_{w}=M_{0} X_{w} \\
X_{w}=\frac{1+P}{1-P}
\end{gathered}
$$

\subsection{DETERMINATION OF POLYMERIZATION DEGREE}

The polymerization degree [20], is determined and calculated according to the following equation:
$\mathrm{X}_{\mathrm{n}}=\mathrm{M}_{\mathrm{n}} / \mathrm{M}_{0}(10)$

\subsection{THE METHOD OF COATS -REDFERN}

The use of thermal analysis in the study of the kinetics of degradation by using the equation of Coats-Redfern [21-22] in the following cases:

For $\mathrm{n}=1$

$\log \left[\frac{-\log (1-\alpha)}{T^{2}}\right]=\log \frac{A R}{q E_{a}}\left[1-\frac{2 R T}{E_{a}}\right]-\frac{E_{a}}{2.303 R T}$

For $\mathrm{n} \# 1$

$\log \left[\frac{1-(1-\alpha)^{1-n}}{T^{2}(1-n)}\right]=\log \frac{A R}{q E_{a}}\left[1-\frac{2 R T}{E_{a}}\right]-\frac{E_{a}}{2.303 R T}$

Where $\alpha$ is the fraction of the sample decomposed at time $t, n$ is the order of the reaction, $\mathrm{T}$ is the temperature, $\mathrm{A}$ is the preexponential factor, $\mathrm{Ea}$ is the activation energy, $\mathrm{R}$ is the gas constant, and $\mathrm{q}$ is the heating rate. This method is an integral method that assumes various orders of reaction and compares the linearity in each case to select the correct order [23].

\subsection{THERMODYNAMIC AND EQUILIBRIUM CONSTANTS}

The entropy calculated from the equation:

$\Delta S^{*}=R\left[\ln \left[\frac{A h}{K T_{s}}\right]\right.$

Where $\mathrm{k}$ and $\mathrm{h}$ are the Boltzmann and Planck constants respectively, $A$ is the preexponential factor, $T_{s}$ is the maximum temperature of the loss in the mass of the curve of TGA.

The Gibbs free energy $(\Delta \mathrm{G})$ and enthalpy $(\Delta \mathrm{H})$ are calculated from the equations :

$\Delta G^{*}=\Delta H^{*}-T_{s} \Delta S^{*}$

$\Delta H^{*}=E_{a}-R T_{s}$

The relationship between Gibbs free energy and equilibrium constant given with equation : 
$\Delta G^{\circ}=-R T \ln K_{e q}$

$\mathrm{R}$ : gas constant. $\mathrm{T}$ : temperature $(\mathrm{K}) . \mathrm{K}_{\text {eq }}$ : equilibrium

constant

The total equilibrium constant for degradation composed of two step is given with:

$$
K_{e q}=\left(K_{e q 1} K_{e q 2}\right)^{\frac{1}{2}}
$$

\section{RESULTS AND DISCUSSION}

The polyamidation reaction in melt phase was carried out at $110,130,135,140$ and $150^{\circ} \mathrm{C}$ was followed by determining the acid number of the reactant acid at each temperature. The reaction could be followed by the fall in acid number of the reactant acid [14-18]. The variation in acid number with time of reaction is tabulated in table 1 . The integral method of analysis was used for studying the kinetics of the reaction. Based on the data available in the literature[14-18] on kinetics of other polyamidation reactions and also by observing the nonlinear trend in the fall of acid number with time, it was assumed that the acid number relation with time would be characterized an overall second-order reaction which is first order with respect to both acid and amine group concentration. Since equivalent amounts of the acid and amine were taken initially and since the reaction is homogeneous.

Using eq. (2), a plot of $1 / A_{v}$ vs. time was drawn and was found to fit the equation quite well up to about $(78,82,76,75,74) \%$ conversion at $\left(110,130,135,140,150^{\circ} \mathrm{C}\right)$.

The relationship between acid number, and inverse of acid number with time at studied temperature is shown in the following figures:

This shows that the polyamidation reaction follows second-order kinetics up to last conversion. It has also been reported in the literature [14-18] that the results of the polyamidation reaction carried out under conditions in which the end group concentrations are relatively low (e.g., conversions above last conversion) indicate that a carboxyl-catalyzed third-order reaction assumes to be the increasing importance and becomes predominant. Hence it was assumed that the reaction would follow an overall third-order kinetics above last conversion, which is second order with respect to the acid group concentration and first order with respect to the amino group concentrations. Since the carboxyl and amino group concentrations are equal. The second order reaction rate constants calculated by the least square analysis of the data of figure 2 are given in Table 2. These rate constants were found to fit the Arrhenius equation well as shown in figure 3. Rate constants are shown in table (2).

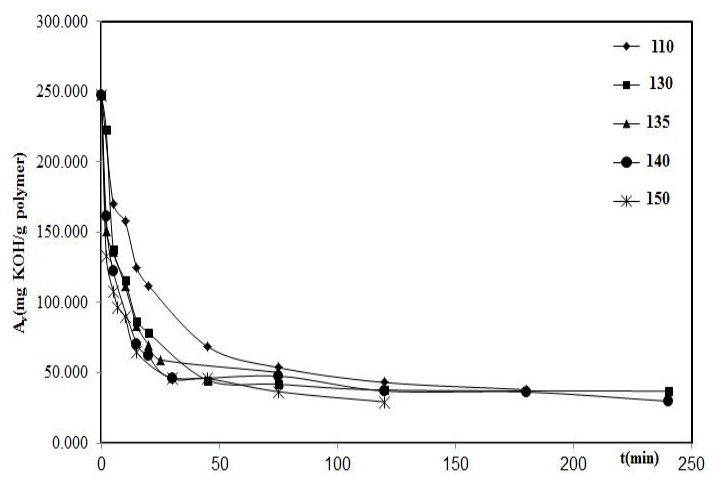

Fig. 1. Changes in Acid value with time at studied temperatures

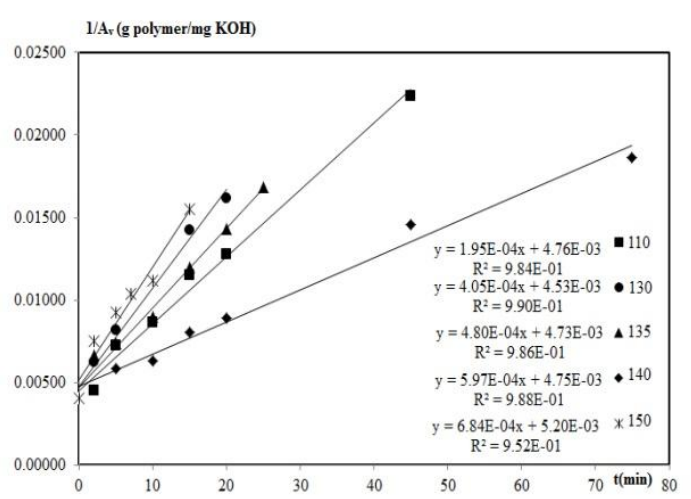

Fig. 2. Changes in (1/Av) with time at studied temperatures 
Yanbu Journal of Engineering and Science Vol. 7 (2013)

TABLE 1: VARIATION OF ACID VALUE WITH REACTION TIME AT VARIOUS TEMPERATURE

\begin{tabular}{|c|c|c|c|c|c|c|c|}
\hline $\mathrm{T}\left({ }^{\circ} \mathrm{C}\right)$ & $\mathrm{t}(\min )$ & $\begin{array}{c}\mathrm{A}_{\mathrm{v}} \\
\text { (mg KOH } \\
\text { /g polymer) } \\
\end{array}$ & $\begin{array}{c}1 / \mathrm{A}_{\mathrm{v}} \\
\text { (g polymer } \\
\text { / } \mathrm{mg} \mathrm{KOH} \text { ) }\end{array}$ & $T(\rho C)$ & $\mathrm{t}(\min )$ & $\begin{array}{c}\mathrm{A}_{\mathrm{V}} \\
\text { (mg KOH } \\
\text { /g polymer) }\end{array}$ & $\begin{array}{c}1 / \mathrm{A}_{\mathrm{V}} \\
\text { (g polymer } \\
\text { / } \mathrm{mg} \mathrm{KOH} \text { ) }\end{array}$ \\
\hline \multirow[t]{9}{*}{110} & 0 & 247.775 & 0.004036 & \multirow[t]{3}{*}{135} & 25 & 59.320 & 0.01686 \\
\hline & 5 & 170.5 & 0.005865 & & 75 & 50.314 & 0.01988 \\
\hline & 10 & 157.8376 & 0.006336 & & 120 & 47.242 & 0.02117 \\
\hline & 15 & 124.5463 & 0.008029 & \multirow[t]{10}{*}{140} & 0 & 247.775 & 0.00404 \\
\hline & 20 & 111.9112 & 0.008936 & & 2 & 160.943 & 0.00621 \\
\hline & 45 & 68.56667 & 0.014584 & & 5 & 122.140 & 0.00819 \\
\hline & 75 & 53.71277 & 0.018618 & & 15 & 70.345 & 0.01422 \\
\hline & 120 & 43.15385 & 0.023173 & & 20 & 61.875 & 0.01616 \\
\hline & 180 & 37.97872 & 0.026331 & & 30 & 46.321 & 0.02159 \\
\hline \multirow[t]{10}{*}{130} & 0 & 247.775 & 0.00404 & & 75 & 47.632 & 0.02099 \\
\hline & 2 & 222.827 & 0.00449 & & 120 & 37.030 & 0.02701 \\
\hline & 5 & 138.177 & 0.00724 & & 180 & 36.334 & 0.02752 \\
\hline & 10 & 115.803 & 0.00864 & & 240 & 29.777 & 0.03358 \\
\hline & 15 & 86.881 & 0.01151 & \multirow[t]{12}{*}{150} & 0 & 247.775 & 0.00404 \\
\hline & 20 & 78.352 & 0.01276 & & 2 & 132.868 & 0.00753 \\
\hline & 45 & 44.701 & 0.02237 & & 5 & 108.116 & 0.00925 \\
\hline & 75 & 41.866 & 0.02389 & & 7 & 96.724 & 0.01034 \\
\hline & 120 & 37.788 & 0.02646 & & 10 & 89.521 & 0.01117 \\
\hline & 240 & 36.952 & 0.02706 & & 15 & 64.426 & 0.01552 \\
\hline \multirow[t]{6}{*}{135} & 0 & 247.775 & 0.00404 & & 30 & 45.886 & 0.02179 \\
\hline & 2 & 151.095 & 0.00662 & & 45 & 45.876 & 0.02180 \\
\hline & 5 & 135.810 & 0.00736 & & 75 & 36.571 & 0.02734 \\
\hline & 10 & 111.753 & 0.00895 & & 120 & 29.257 & 0.03418 \\
\hline & 15 & 83.731 & 0.01194 & & 75 & 50.314 & 0.01988 \\
\hline & 20 & 69.875 & 0.01431 & & 120 & 47.242 & 0.02117 \\
\hline
\end{tabular}




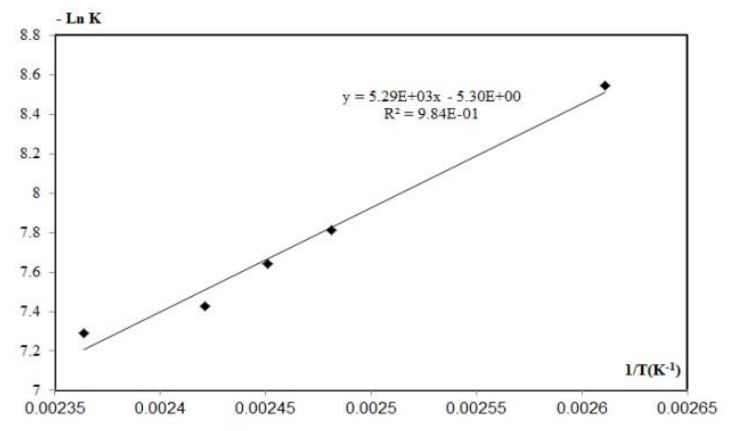

Fig.3.change in -Log $\mathrm{K}$ with inverse of temperature

TABLE 2: REACTION RATE CONSTANTS AT VARIOUS TEMPERATURES

\begin{tabular}{|c|c|c|c|}
\hline $\mathrm{T}\left({ }^{\circ} \mathrm{C}\right)$ & $\mathrm{T}(\mathrm{K})$ & $1 / \mathrm{T}\left(\mathrm{K}^{-1}\right)$ & $(\text { con })^{1-\mathrm{n}}(\text { time })^{-1} \mathrm{k}$ \\
\hline 110 & 383 & 0.002611 & $1.95 \times 10^{-4}$ \\
\hline 130 & 403 & 0.002481 & $4.05 \times 10^{-4}$ \\
\hline 135 & 408 & 0.002451 & $4.80 \times 10^{-4}$ \\
\hline 140 & 413 & 0.002421 & $5.97 \times 10^{-4}$ \\
\hline 150 & 423 & 0.002364 & $6.84 \times 10^{-4}$ \\
\hline
\end{tabular}

The activation energy for the second order reaction were calculated from the least square analysis of the data of figure 3 and was found to be $43.981 \mathrm{k} \mathrm{J} / \mathrm{mol}$.

\subsection{MOLECULAR WEIGHTS FOR PREPARED POLYAMIDES}

The molecular weight is considered one of the most important properties of polymers that depends on most mechanical and physical properties of polymer besides to other technological usages. Strength and elasticity of polymers is due to interfusion and hitching of the polymeric long gamuts with each other. The molecular weights of elasticity polymers should be higher than adhesives which have fewer weights relatively. So, dominance of molecular weights during the production is very important. The degree of polymerization, number average molecular weight and weight average molecular weight have been calculated during different times. The tables [3 to 7] show the values of conversion degree, the number average of molecular weight, and polymerization degree through the time of studied temperatures.

TABLE 3: VARIATIONS OF CONVERSION DEGREE, THE NUMBER AVERAGE OF MOLECULAR WEIGHT, AND POLYMERIZATION DEGREE WITH REACTION TIME AT $110^{\circ} \mathrm{C}$

\begin{tabular}{|l|l|l|l|l|}
\hline $\mathrm{T}(\mathrm{min})$ & $\begin{array}{l}\mathrm{M}_{\mathrm{n}} \\
(\mathrm{g} / \mathrm{mole})\end{array}$ & $\begin{array}{l}\mathrm{M}_{\mathrm{w}} \\
(\mathrm{g} / \mathrm{mole})\end{array}$ & $\mathrm{X}_{\mathrm{n}}$ & $\mathrm{P} \%$ \\
\hline 0 & 664.230 & 664.230 & 1.00 & 0.000 \\
\hline 5 & 965.276 & 1266.322 & 1.45 & 0.312 \\
\hline 10 & 1042.715 & 1421.199 & 1.57 & 0.363 \\
\hline 15 & 1321.433 & 1978.635 & 1.99 & 0.497 \\
\hline 20 & 1470.627 & 2277.023 & 2.21 & 0.548 \\
\hline 45 & 2400.286 & 4136.341 & 3.61 & 0.723 \\
\hline 75 & 3064.068 & 5463.907 & 4.61 & 0.783 \\
\hline 120 & 3813.787 & 6963.345 & 5.74 & 0.826 \\
\hline 180 & 4333.468 & 8002.706 & 6.52 & 0.847 \\
\hline
\end{tabular}

TABLE 4: VARIATIONS OF CONVERSION DEGREE, THE NUMBER AVERAGE OF MOLECULAR WEIGHT, AND POLYMERIZATION DEGREE WITH REACTION TIME AT $130^{\circ} \mathrm{C}$

\begin{tabular}{|c|c|c|c|c|}
\hline $\mathrm{T}(\mathrm{min})$ & $\begin{array}{l}M_{n} \\
(g / \text { mole })\end{array}$ & $\begin{array}{l}M_{w} \\
(g / \text { mole })\end{array}$ & $X_{n}$ & $\mathrm{P} \%$ \\
\hline 0 & 664.23 & 664.23 & 1 & 0.000 \\
\hline 2 & 738.598 & 812.965 & 1.11 & 0.101 \\
\hline 5 & 1191.075 & 1717.920 & 1.79 & 0.442 \\
\hline 10 & 1421.206 & 2178.182 & 2.14 & 0.533 \\
\hline 15 & 1894.321 & 3124.411 & 2.85 & 0.649 \\
\hline 20 & 2100.517 & 3536.803 & 3.16 & 0.684 \\
\hline 45 & 3681.772 & 6699.313 & 5.54 & 0.820 \\
\hline 75 & 3931.135 & 7198.039 & 5.92 & 0.831 \\
\hline 120 & 4355.390 & 8046.550 & 6.56 & 0.847 \\
\hline 240 & 4453.863 & 8243.497 & 6.71 & 0.851 \\
\hline
\end{tabular}


TABLE 5: VARIATIONS OF CONVERSION DEGREE, THE NUMBER AVERAGE OF MOLECULAR WEIGHT, AND POLYMERIZATION DEGREE WITH REACTION TIME AT $135^{\circ} \mathrm{C}$

\begin{tabular}{|c|c|c|c|c|}
\hline $\mathrm{T}(\mathrm{min})$ & $\begin{array}{c}\mathrm{M}_{\mathrm{n}} \\
(\mathrm{g} / \mathrm{mole})\end{array}$ & $\begin{array}{c}\mathrm{M}_{\mathrm{w}} \\
(\mathrm{g} / \mathrm{mole})\end{array}$ & $\mathrm{X}_{\mathrm{n}}$ & $\mathrm{P} \%$ \\
\hline 0 & 664.230 & 664.230 & 1.00 & 0.000 \\
\hline 2 & 1089.248 & 1514.266 & 1.64 & 0.390 \\
\hline 5 & 1211.837 & 1759.443 & 1.82 & 0.452 \\
\hline 10 & 1472.709 & 2281.187 & 2.22 & 0.549 \\
\hline 15 & 1965.567 & 3266.905 & 2.96 & 0.662 \\
\hline 20 & 2355.328 & 4046.426 & 3.55 & 0.718 \\
\hline 25 & 2774.425 & 4884.621 & 4.18 & 0.761 \\
\hline 75 & 3271.056 & 5877.882 & 4.92 & 0.797 \\
\hline 120 & 3483.748 & 6303.266 & 5.24 & 0.809 \\
\hline
\end{tabular}

TABLE 6: VARIATIONS OF CONVERSION DEGREE, THE NUMBER AVERAGE OF MOLECULAR WEIGHT ,AND POLYMERIZATION DEGREE WITH REACTION TIME AT $140^{\circ} \mathrm{C}$

\begin{tabular}{|c|c|c|c|c|}
\hline $\mathrm{T}(\mathrm{min})$ & $\begin{array}{c}\mathrm{M}_{\mathrm{n}} \\
(\mathrm{g} / \mathrm{mole})\end{array}$ & $\begin{array}{c}\mathrm{M}_{\mathrm{w}} \\
(\mathrm{g} / \mathrm{mole})\end{array}$ & $\mathrm{X}_{\mathrm{n}}$ & $\mathrm{P} \%$ \\
\hline 0 & 664.230 & 664.230 & 1.00 & 0.000 \\
\hline 2 & 1022.598 & 1380.966 & 1.54 & 0.350 \\
\hline 5 & 1347.471 & 2030.711 & 2.03 & 0.507 \\
\hline 15 & 2339.612 & 4014.994 & 3.52 & 0.716 \\
\hline 20 & 2659.872 & 4655.514 & 4.00 & 0.750 \\
\hline 30 & 3553.015 & 6441.801 & 5.35 & 0.813 \\
\hline 75 & 3455.226 & 6246.222 & 5.20 & 0.808 \\
\hline 120 & 4444.529 & 8224.828 & 6.69 & 0.851 \\
\hline 180 & 4529.606 & 8394.982 & 6.82 & 0.853 \\
\hline 240 & 5527.058 & 10389.886 & 8.32 & 0.880 \\
\hline
\end{tabular}

TABLE 7: VARIATIONS OF CONVERSION DEGREE, THE NUMBER AVERAGE OF MOLECULAR WEIGHT ,AND POLYMERIZATION DEGREE WITH REACTION TIME AT $150^{\circ} \mathrm{C}$

\begin{tabular}{|c|c|c|c|c|}
\hline $\mathrm{T}(\mathrm{min})$ & $\begin{array}{c}\mathrm{M}_{\mathrm{n}} \\
(\mathrm{g} / \mathrm{mole})\end{array}$ & $\begin{array}{c}\mathrm{M}_{\mathrm{w}} \\
(\mathrm{g} / \mathrm{mole})\end{array}$ & $\mathrm{X}_{\mathrm{n}}$ & $\mathrm{P} \%$ \\
\hline 0 & 664.230 & 664.230 & 1.00 & 0.000 \\
\hline 2 & 1238.666 & 1813.102 & 1.86 & 0.464 \\
\hline 5 & 1522.255 & 2380.281 & 2.29 & 0.564 \\
\hline 7 & 1701.536 & 2738.842 & 2.56 & 0.610 \\
\hline 10 & 1838.441 & 3012.652 & 2.77 & 0.639 \\
\hline 15 & 2554.560 & 4444.891 & 3.85 & 0.740 \\
\hline 30 & 3586.695 & 6509.160 & 5.40 & 0.815 \\
\hline 45 & 3587.475 & 6510.719 & 5.40 & 0.815 \\
\hline 75 & 4500.269 & 8336.308 & 6.78 & 0.852 \\
\hline 120 & 5625.336 & 10586.442 & 8.47 & 0.882 \\
\hline
\end{tabular}

The above tables show that the polymerization degree has become 8.47 , the number average of molecular weight is 5625.336 and the weight average of molecular degree is 10586.442 at $145^{\circ} \mathrm{C}$ whereas polymerization degree ranged between 5.20 8.47. The relationship between number average of molecular weight, weight average of molecular weight, and polymerization degree with time is shown in figures $(4,5$, and 6) where it was found linear $(78,82,76,75,74) \%$ conversion at $110,130,135,140,150{ }^{\circ} \mathrm{C}$. This is observed in the figures (4, 5 and 6).

We notice from the previous forms that all of number average of molecular weight, the weight average of molecular weight and the degree of polymerization increases gradually with time, it due to the growth of polymer chains. 


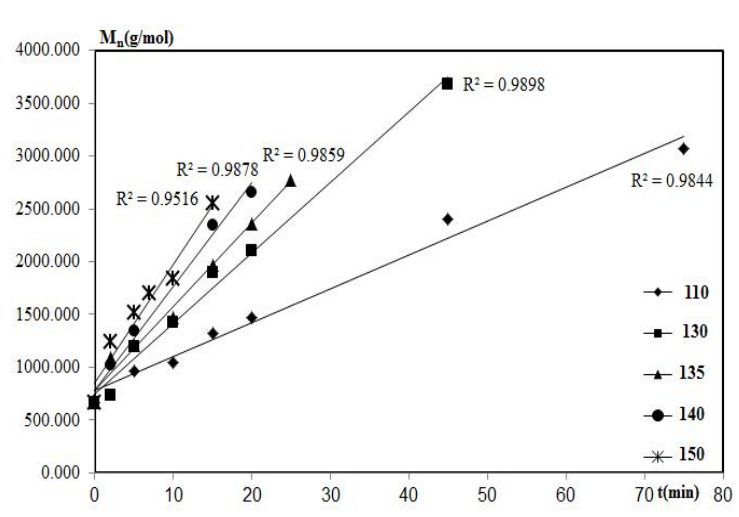

Fig .4. Change in the number average of molecular weight with time at studied temperatures

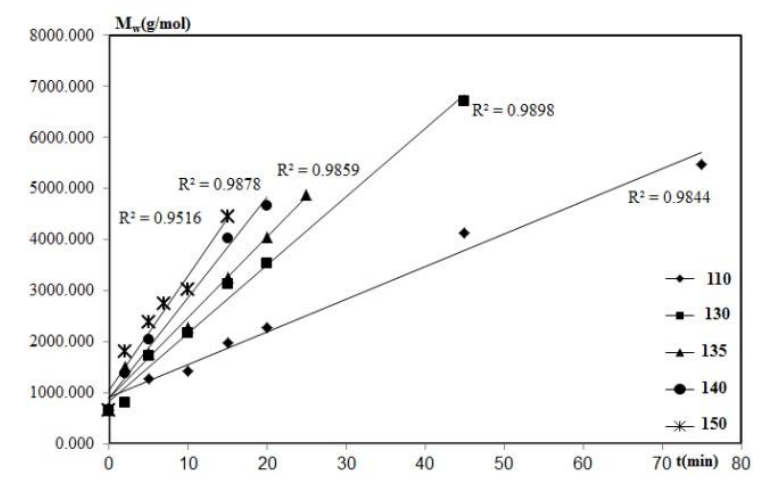

Fig. 5. Change in the number average of molecular weight with time at studied temperatures

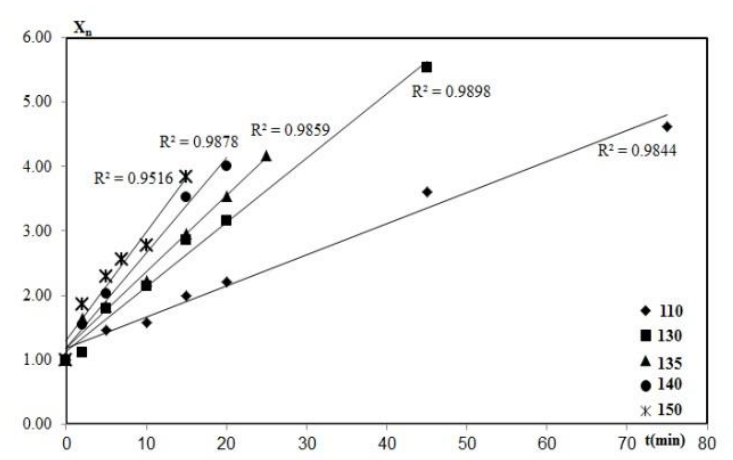

Fig. 6. Change in polymerization degree with time at studied temperatures

\subsection{THERMAL STUDY AND KINETIC AND} THERMODYNAMIC PARAMETERS:

Since the thermodynamic parameters $(\Delta \mathrm{H}$, $\Delta \mathrm{G}, \Delta \mathrm{S})$ can not to obtained through reactions at different temperatures, we resort to study the thermal degradation using the technique of thermogravimetric analysis (TGA). TGA curves recorded for the successive steps of the processes of degradation of the polyamide, so we must determine the parameters for each step in the reaction:

$\left(T_{b}\right)$ : is the elementary temperature at which degradation begins

$\left(T_{\mathrm{f}}\right)$ : is the final temperature at which degradation finished

$\left(T_{\text {max }}\right)$ : Is the maximum temperature of the loss in the mass, It was determined from the tangent for the TGA curve.

A very small amount of polymer $(8.8153 \mathrm{mg})$ in a small pot of aluminum and placed in oven of the device, the device programmed thermally so that the speed of heating is equal to $\left(10{ }^{\circ} \mathrm{C} / \mathrm{min}\right)$ and it was recorded continuous change of the mass for the temperature under a controlled atmosphere in the presence of nitrogen gas. Here the temperature is increased at a programed linear rate. TGA curve shows the loss of weight as a result of the degradation of the sample. Figure (7) illustrate TGA curve of the studied polymer.

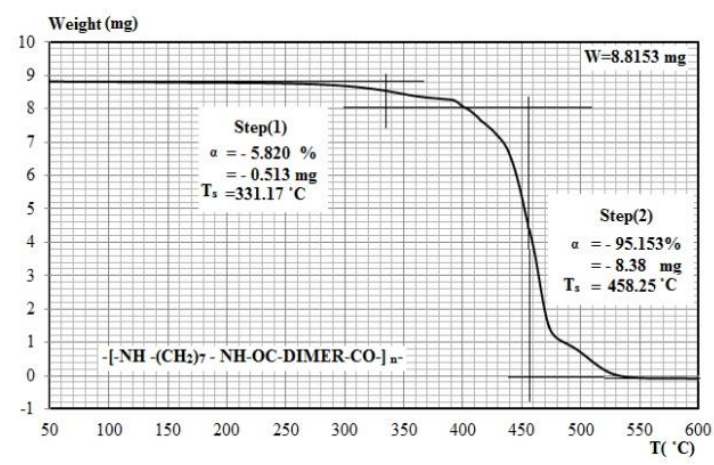

Fig.7. TGA curve of the studied polymer

The activation energy calculated from the slope of the resulting line of the plot of:

$\log \left[\frac{1-(1-\alpha)^{1-n}}{T^{2}(1-n)}\right]$ vs $1 / \mathrm{T}$

Tables (8) and (9) illustrate values from the slope the result line drawing that presented in figures 8 and 9 . 
$\log \left[\frac{1-(1-\alpha)^{1-n}}{T^{2}(1-n)}\right]$ vs $1 / \mathrm{T}$

We got the activation energy from the equation $E a=2.303 m R$, pre-exponential factor determined from the intercept, we notice from the last forms that $\left(\mathrm{R}^{2}=0.997\right)$ for the degradation of the first stage and $\left(\mathrm{R}^{2}=\right.$ 0.9995 ) for degradation of the second stage in both cases.

TABLES 8: VALUES $\log \left[\frac{1-(1-\alpha)^{1-n}}{T^{2}(1-n)}\right]$ VS $1 / \mathrm{T}$ FOR N $=2 \operatorname{STEP}(1, \mathrm{~A}=5.820 \%)$

\begin{tabular}{|l|l|c|c|}
\hline $\mathrm{T}(\mathrm{K})$ & $1 / \mathrm{T}\left(\mathrm{K}^{-1}\right)$ & $\log \left[\frac{1-(1-\alpha)^{1-n}}{T^{2}(1-n)}\right]$ & \multirow{2}{*}{ Slope } \\
\hline 463 & 0.00216 & -6.5402 & \\
\hline 513 & 0.001949 & -6.62927 & \multirow{2}{*}{478.665} \\
\hline 563 & 0.001776 & -6.71005 & \\
\hline 613 & 0.001631 & -6.78396 & \\
\hline 663 & 0.001508 & -6.85206 & \\
\hline
\end{tabular}

TABLES 9: VALUES $\log \left[\frac{1-(1-\alpha)^{1-n}}{T^{2}(1-n)}\right]$ VS $1 /$ T FOR N $=2 \operatorname{STEP}(2, \mathrm{~A}=95.153 \%)$

\begin{tabular}{|l|l|c|c|}
\hline $\mathrm{T}(\mathrm{K})$ & $1 / \mathrm{T}\left(\mathrm{K}^{-1}\right)$ & $\log \left[\frac{1-(1-\alpha)^{1-n}}{T^{2}(1-n)}\right]$ & \multirow{2}{*}{ Slope } \\
\hline 703 & 0.001422 & -4.40096 & \\
\hline 733 & 0.001364 & -4.43726 & \\
\hline 763 & 0.001311 & -4.4721 & \\
\hline 793 & 0.001261 & -4.5056 & \\
\hline 823 & 0.001215 & -4.53785 & \\
\hline
\end{tabular}

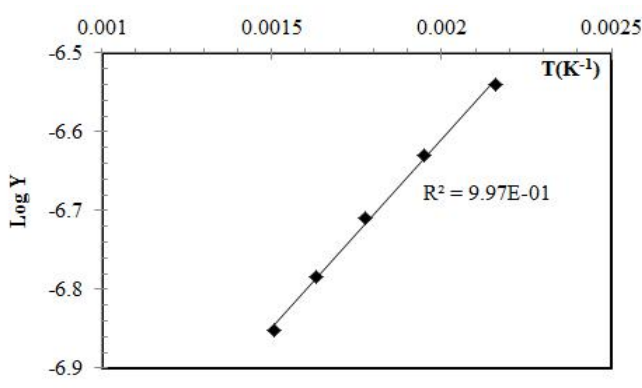

Fig.8.change in $\log Y=\log \left[\frac{1-(1-\alpha)^{1-n}}{T^{2}(1-n)}\right]$ with inverse of temperature for step 1 .

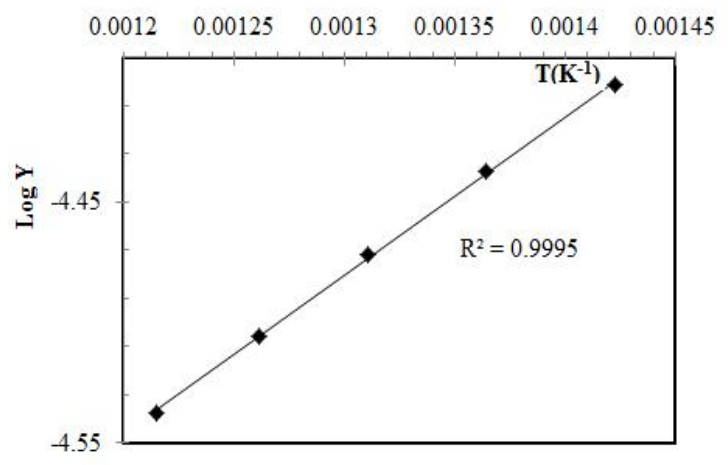

Fig. 9 .change in $\log Y=\log \left[\frac{1-(1-\alpha)^{1-n}}{T^{2}(1-n)}\right]$ with inverse of temperature for step 2 .

Tables (10) illustrates values of equation (3) for degradation.

TABLES 10: VALUES OF ARRHENIUS EQUATION FOR DEGRADATION

\begin{tabular}{|l|l|l|}
\hline Rate constants & Step(1) & Step(2) \\
\hline $\mathrm{T}_{\mathrm{s}}(\mathrm{K})$ & 551.1 & 731.25 \\
\hline $\mathrm{Ea}(\mathrm{Kj} / \mathrm{mol})$ & 9.165 & 12.637 \\
\hline $\left.\mathrm{mol}^{-1} \cdot \mathrm{min}^{-1}\right)(\mathrm{A}$ & 6.090 & 11.439 \\
\hline $\left.\mathrm{mol}^{-1} \cdot \mathrm{min}^{-1}\right)(\mathrm{k}$ & 0.982 & 1.431 \\
\hline
\end{tabular}

A is the Arrhenius factor determined from the secant intercept on the axis $Y$.

The activation energy and thermodynamic and equilibrium constants has been calculated according to the last equations, Table (11) illustrate its values. 
TABLES 11: VALUES ACTIVATION ENERGY AND THERMODYNAMIC AND EQUILIBRIUM CONSTANTS

\begin{tabular}{|c|c|c|c|}
\hline $\begin{array}{c}\text { Thermodynamic } \\
\text { constants }\end{array}$ & Step(1) & Step(2) & Step (1+2) \\
\hline $\mathrm{T}_{\mathrm{s}}(\mathrm{K})$ & 604.17 & 731.25 & - \\
\hline$\alpha(\%)$ & 5.820 & 95.153 & - \\
\hline $\mathrm{Ea}(\mathrm{Kj} / \mathrm{mol})$ & 9.165 & 12.637 & 21.802 \\
\hline$\Delta \mathrm{S}(\mathrm{Kj} / \mathrm{mol} \mathrm{K})$ & -0.236 & -0.232 & -0.468 \\
\hline$\Delta \mathrm{H}(\mathrm{Kj} / \mathrm{mol})$ & 4.142 & 6.557 & 10.699 \\
\hline$\Delta \mathrm{G}(\mathrm{Kj} / \mathrm{mol})$ & 146.607 & $\begin{array}{c}176.315 \\
322.922\end{array}$ \\
\hline$(\mathrm{K}$ eq $)$ & $2.111 \times 10^{-}$ & $\begin{array}{c}2.541 \times 10^{-} \\
13\end{array}$ & $\begin{array}{c}2.3161 \times 10^{-} \\
13\end{array}$ \\
\hline
\end{tabular}

Values in the table (the resulting compound is solid) if change of entropy was positive the sample would not be a solid, and thus the reaction occur coercive (the degradation forced to occur by heating) ( $\Delta \mathrm{G}$ positive), we have got very small equilibrium constant due to the reaction is endothermic (the reaction is reversible). However, the reaction is speed when the temperature increases.

\subsection{INFRA-RED SPECTRUM}

The FT-IR spectrum of dimer acid-based polyamide were obtained using Infra-red device. Polyamide was thoroughly ground with $\mathrm{KBr}$ (IR, grade, Merck - Germany) (at a ratio of $1: 200)$ and pressed into a pellet and then the spectrum was recorded. The FT-IR spectrum of dimer acid-based polyamide with 1,7 diamino heptane is shown in fig (10).

Since the reaction is endothermic, and this is illustrated from the positive values of $\Delta \mathrm{H}$ which is shown in the previous table, as the degradation occur by heating (endothermic), it gives a more regular particles ( $\Delta S$ negative) , we have noticed its negative.

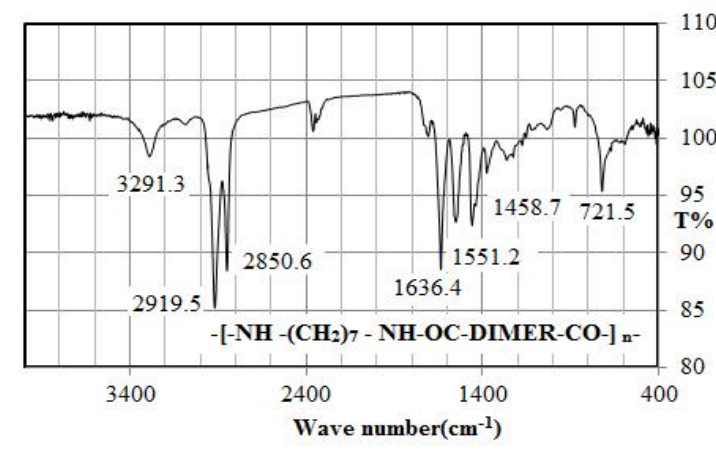

Fig . 10 . infra- Red spectrum for resulted polyamide

Figure (10) illustrates Stretching band at $\left(1636.4 \mathrm{~cm}^{-1}\right)$ due to group $\mathrm{CO}$, where the bond $\mathrm{N}-\mathrm{H}$ have Stretching band at $(1551.2$ $\left.\mathrm{cm}^{-1}\right)$, the present bands at $\left(721.5 \mathrm{~cm}^{-1}\right)$ due to methylene groups in dimer acid, while the absorption band of $\mathrm{N}-\mathrm{H}$ appears at a wavelength $\left(3291.3 \mathrm{Cm}^{-1}\right)$ [24-27].

\section{CONCLUSION}

The polyamidation reaction in melt phase follows an overall second-order kinetics up to $78,82,76,75,74 \%$ conversion at 110 , $130,135,140,150{ }^{\circ} \mathrm{C}$ with an activation energy of

$43.981 \mathrm{k} \mathrm{j} / \mathrm{mol}$. The relationship between the number average of molecular weight, the weight average of molecular weight, and polymerization degree with time is linear until $(78,82,76,75,74) \%$ conversion at $(110$, $130,135,140,150{ }^{\circ} \mathrm{C}$, the kinetic of degradation was found to be of overall second order.

\section{ACKNOWLEDGMENT}

The authors thanks Damascus university for providing all equipment's the research, as well as Miss Kafaa'Al Salah for lingual help.

\section{REFERENCE}

[1] Ebewele, R.O, Polymer science and technology, University of Benin .Nigeria.) P161. (1996).

[2] Brydson ,J,A. Plastics Materials, University of North London, p 478- 480 . (1999).

[3] Fan ,XD . Deng, Y. Waterhouse ,J . Pfromm ,P . Synthesis and characterization of polyamide resins 
from soy-based dimer acids and different amides. J. Appl. Polym. Sci,68(2):305-314. (1998).

[4] Chen,X. Zhong, H. Jia, L. Ning, J. Tang, R. Qiao ,J. Zhang ,Z. Polyamides derived from piperazine and used for hot-melt adhesives; Synthesis and properties. Int ,J.Adhes,22.:75-79. (2002).

[5] Hablot, E. Donnio, B. Bouquey, M. Averous ,A . Dimer acid-based thermoplastic bio-polyamides: reaction kinetics, properties and structure, polymer .J:51.;5895. (2010).

[6] Brandrup, J. Immergut ,EH. Grulke ,EA. Abe, A. Bloch, DR., polymer hand bock ;WileyInterscience:.4thed.New-york(1999).

[7] Deng, Y. Fan ,XD. Waterhouse, J. Synthesis and characterization of soy-based copolyamides with different $\alpha$-amino acids. J. Appl. Polym. Sci, 73:1081-1088. (1999).

[8] Vedanayagam ,H ,S. Kale, V. Non-reactive polyamides from C36 dimer acids: preparation and properties, Ind .Inst . Chem ,Technol, 33(16)3495-3499. ( 1992).

[9] Averous,L. Hablot ,E. Matadi,R .Ahzi,S. Renewable biocomposites of dimer fatty acid based polyamides with cellulose fibres : thermal ,physical and mechanical properties , Compos Sci andTechnol,70:504-509. (2010).

[10] Matadi, R .Hablot, E. wang, K . Bahlouli, N. Ahzi, S. Averous, L High Strain rate Behavior of Renewable biocomposites based on dimer fatty acid polyamides and cellulose fibres :Compos Sci and Technol,71:674-682. (2011).

[11] Vaudemond,R. Hablot ,E. Matadi,R .Ahzi,S. Ruch,D. Averous,L. Yield Behavior of Renewable bio composites of dimer fatty acid -based polyamides with cellulose fibres : Compos Sci Technol,70:525-529. (2010).

[12] Cavus,S . Gurkaynak, M.A. Influence of monofunctional reactants on the physical properties of dimer acid-based polyamides , polym. Adv. Technol, 17: 30-36(2006) .

[13] Guidici, R. Mathematical modeling of an industrial process of nylon- 66 polymerization in a two phase flow tubular reactor ,Chemical Engineering Science, 54:3243. (1999).

[14] Kale,V. Vedanayagam, H.S . Rao, M.B . Devi, K.S . Rao, S.V . Lakshminarayana, G, Kinetics of reaction of ethylenediamine and dimeric fatty acids, J. Appl. Polym. Sci., 36:1517-1524. (1988).
[15] Vedanayagam, H.S. Kale, V . Subbarao, R . Kinetics of reaction of $\mathrm{C}_{36}$ dimeric fatty acids and ethylenediamine in solution, J. Appl. Polym. Sci. 45: 2245-2248.(1992)

[16] Heidarian, J . Ghasem, N.M . Daud, W. Kinetic model for polymerization of dimer fatty acids with ethylenediamine, University of Malaya pada,45: 135. (2003).

[17] Heidarian, J . Ghasem, N.M . Ashri,M. Daud, W. Study on kinetics of polymerization of dimer fatty acids with ethylenediamine in the presence of catalyst, J. Appl. Polym. Sci.100: 85- 93. (2004).

[18] Heidarian, J . Ghasem, N.M . Ashri,M. Daud, W. Kinetics of Polymerization of Dimer Fatty Acid with Ethylenediamine After 90\% Conversion, J.polym.Sci, 206(6): 658-663. (2005).

[19] N.P. Chermisinoff, Polymer Characterization Laboratory techniques and Analysis, Westwood, New Jersey, U.S.A,07675, P :17-23. (1996) .

[20] Braun, D. Cherdron ,H, Ritter , Hpolymer synthesis: theory and practice, Springer - verlag berlin Heidelberg New York,p221. .(2001).

[21] S. Maitra, N.Chakvabarty , J. Pramanik, Decomposition Kinetics of alkaline earth carbonates by integral approximation method , ceramic ,V (54) P(268-272), (2008).

[22] A.M. Shehap, Thermal and Spectroscopic studies of polyvinyl Alcohol / Carboxy Methyl celluloses Blends. Egypt .J.solids,vol (31) No(1) (75-91). (2008),

[23] Y.Tonbul , K.Yurdakoj , thermogravimetric investigation of the Dehydration ,Turkish bentonite, Turk . J. Chem, V25,P33-339. (2001).

[24] Cho SH,Jhon MS,Yuk SH, Lee HB. Temperature- induced phase transition of poly (N,N- dimethyllaminoethyl methacrylate -coacrylamide).J.polym.Sci. B:polym .phys.; 35(4) : 595-598. ( 1997).

[25] Cho SH,Jhon MS,Yuk SH, Temperaturesensitive swelling behavior of polymer gel composed of poly (N,N-dimethyllaminoethyl methacrylate )and its copolymers . Eur, polym. J. ; 35: 1841-1845. (1999).

[26] Zhang X-Z ,Zhang J-T,Zhuo R-X ,Chu C$\mathrm{C}$,Synthesis and properties of thermosensitive , crown ether incorporated poly( Nisopropylacrylamide) hydrogel .polymer; 43:4823-4827,(2002). 
[27] Bajpai A ,Khare K, Direct polycondensation of castor oil based dimer acid and aromatic diamines using triphenyl-phosphite .J. Macromol.Sci.Pur Chem. A41(3):275-293.( 2004). 


\section{دراسة حركية تفاعل الحمض الديميري المهرج C36مع 1،1 ـ ثنائي امينو الهيتان و تعيين الثوابت الترموديناميكية}

$$
\text { حسن المحمد ومنال الحموي و احمد فلاح }
$$

الملخص:

نفذت الدراسة الحركية على التفاعل بين1،7 - ثنائيامينو الهبتانو الحمض الديميري المهدرج C36 في الحالة المنصهرة ، أنجز التفاعل عند الدرجات (C150.140.135.130,110م) وجرى تعيين قرينة الحموضة للحمض المتفاعل ـ وقد وجد بأن تفاعل الأميدة كان من المرتبة الثانية مع طاقة تتشيط 44.0 kJ/mol حتى نسب

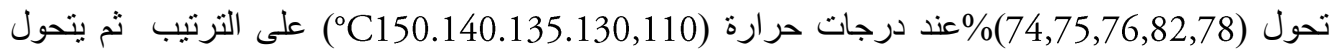
التفاعل من المرتبة الثانية إلى المرتبة الثالثة فوق نسب التحول السابقة. قمنا بتعيين درجة البلمرة وكل من معدل الوزن الجزيئي العددي والوزني خلال أزمنة مختلفة ولوحظ أن علاقة كل من معدل الوزن الجزيئي العددي والوزني و درجة البلمرة مع الزمن علاقة خطية حتى نسب تحول (74,75,76,82,78)

نفذت الدراسة الحركية لتفكك البولي أميد الناتج باستخدام التحليل الحراري (TGA) ، تم تحديد الثوابت الترموديناميكية وثو ابت التوازن للتفكك، وجد بأن حركية التفكك تتبع مرتبة ثانية، تم التأكد من بنية البولي أميد الناتج باستخدام مطيافية ماتحت الأحمر. 